\title{
PHYTOCHEMICAL ANALYSIS AND EVALUATION OF SCAVENGING ACTIVITY OF METHANOLIC EXTRACT OF ADENANTHERA PAVONINA LINN LEAVES
}

\author{
*Mohd. Mujahid ${ }^{1}$, Hefazat H. Siddiqui ${ }^{1}$, Arshad Hussain ${ }^{2}$, MD. Azizur Rahman ${ }^{1}$, Mohd. Khushtar ${ }^{1}$, Yasmeen Jahan ${ }^{1}$ \\ ${ }^{1}$ Faculty of Pharmacy, Integral University, Dasauli, Kursi Road, Lucknow, Uttar Pradesh- 226026, India \\ ${ }^{2}$ Bio-active Research Laboratory, Faculty of Pharmacy, Integral University, Dasauli, Kursi Road, Lucknow, Uttar
}

Pradesh- 226026, India

Received 12 March 2015; Review Completed 07 April 2015; Accepted 02 May 2015, Available online 15 May 2015

\begin{abstract}
Aim: Reactive oxygen species (ROS) such as superoxide anion, hydrogen peroxide and hydroxyl radicals are involved in the oxidative damages resulting in pathogenesis of the various disorders and diseases. Thus, the scavenging activity of methanolic extract of Adenanthera pavonina Linn leaves (MEAP) was evaluated to find the ability to counteract oxidative damages by ROS.

Materials and methods: Total phenolic and flavonoid contents were determined by colorimetric principle using gallic acid and rutin calibration curves respectively. Scavenging activity was evaluated by DPPH free radical and nitric oxide anion scavenging assays. Total reducing power was also evaluated.

Results: Phytochemical analysis of MEAP showed the presence of alkaloids, glycosides, carbohydrates, phenolic compounds, tannins, flavonoids, terpenoids, saponins, sterols, proteins and resins. Total ash, acid insoluble and water soluble ash values were found to be $8.86,2.24$ and $7.18 \%$ w/w respectively. Loss on drying was found to be $1.53 \% \mathrm{w} / \mathrm{w}$. Extractive value was found to be $11.2 \% \mathrm{w} / \mathrm{w}$. Total phenolic and flavonoid contents in MEAP were found to be $55.43 \pm 1.07 \mu \mathrm{g} / \mathrm{ml}$ equivalent to gallic acid and $52.87 \pm 1.8 \mu \mathrm{g} / \mathrm{ml}$ equivalent to rutin. The $\mathrm{IC}_{50}$ values for the scavenging of $\mathrm{DPPH}$ free radical and nitric oxide anion were found to be $425 \mu \mathrm{g} / \mathrm{ml}$ and $352 \mu \mathrm{g} / \mathrm{ml}$ as compared to that of standard ascorbic acid $320 \mu \mathrm{g} / \mathrm{ml} \mathrm{and} 280 \mu \mathrm{g} / \mathrm{ml}$ respectively. Total reducing power was found to be increasing with increasing doses of extract.

Conclusion: Methanolic extract of Adenanthera pavonina Linn leaves is a potent scavenger of ROS and can counteract oxidative damages by ROS. Thus, MEAP can be employed as an anti-oxidant drug to counteract and treat oxidative damages by ROS.
\end{abstract}

Keywords: Adenanthera pavonina, ROS, scavenging activity, Phenolics, Flavonoids.

\section{INTRODUCTION}

Oxidative stress has a major role in the pathogenesis of diverse diseases such as atherosclerosis, liver cirrhosis including cancer ${ }^{1}$. It is initiated by reactive oxygen species (ROS) such as superoxide anion $\left(\mathrm{O}^{-2}\right)$, perhydroxy radical $\left(\mathrm{HOO}^{-}\right)$and hydroxyl radical $\left(\mathrm{HO}^{-}\right)$. These radicals are formed by one electron reduction process of molecular oxygen $\left(\mathrm{O}_{2}\right)$. ROS can easily initiate the lipid peroxidation of the membrane lipids causing damage to the cell membrane of phospholipids and many other lipoproteins by propagating a chain reaction ${ }^{2}$. The abundant evidences suggested that ROS such as superoxide anion, hydrogen peroxide and hydroxyl radicals are involved in the pathogenesis of the various disorders and diseases ${ }^{3}$. Thus, antioxidants defense systems have co-evolved with aerobic metabolism to counteract oxidative damage from ROS. Antioxidants are exogenous (natural or synthetic) or endogenous compounds acting in several ways including by removal of oxygen, scavenging ROS/nitrogen species or their precursors, inhibiting ROS formation and binding metal ions needed for catalysis of ROS generation and by up-regulation of endogenous antioxidant defenses. The protective efficacy of antioxidants depends on the type of ROS (c) 2011-15, JDDT. All Rights Reserved that is generated, the place of generation and the severity of the damage ${ }^{4,5}$.

Adenanthera pavonina Linn (A. pavonina) belonging to family fabaceae is commonly known as red wood and red-bread tree which is a deciduous tree, 18-24 m tall, erect and $60 \mathrm{~cm}$ in diameter ${ }^{6}$. Many species of Adenanthera including A. pavonina have been used as traditional herbal medicine against a variety of diseases including diabetes, lipid disorders, diarrhoea, haemorrhage from the stomach, haematuria and as antiinflammatory agent in gout. Traditionally, its ground seed is widely used for the treatment of various human ailments such as boils, cholera, paralysis, epilepsy, spasm, inflammation, blood disorders, arthritis, hepatoprotective, rheumatism, indigestion and convulsion $^{7,8}$.

*Corresponding author: Mr. Mohd Mujahid Assistant Professor, Faculty of Pharmacy, Integral University, Dasauli, Kursi Road, Lucknow, Uttar Pradesh-226026, India Mobile No.: +919506572805 E-mail: mujahidiu@gmail.com 
Phytochemically, its seed contains an anti-inflammatory active principle, $O$-acetylethanolamine. The leaves possess octacosanol, dulcitol, glucosides of $\beta$-sitosterol and stigmasterol. The bark furnishes stigmasterol glucoside, and pods contain glycosides, saponins and steroids ${ }^{9-11}$. A new five-membered lactone ring with an exo-cyclic double bonded compound, pavonin was isolated from the its methanol soluble part ${ }^{12}$. The methanolic extract of seed has also been reported to demonstrate anti-inflammatory and analgesic activities 13. The crude extract of $A$. pavonina showed blood pressure lowering effect antifungal, anti-oxidant and cytotoxic, anti-diabetic and antihyperlipidemic activities 13-16

\section{MATERIALS AND METHODS}

\section{Collection and authentification of plant material}

The fresh leaves of A. pavonina were collected from Pallavaram, Chennai, Tamilnadu in the month of June 2010. The plant specimen was authenticated by National Institute of Herbal Science, Plant Anatomy Research Center, Chennai, Tamilnadu (References no.: PARC/2011/954).

\section{Preparation of extract}

Freshly collected leaves of A. pavonina were washed with distilled water to remove dirt and soil and dried under shade in a ventilated room. Coarsely powdered drug $(500 \mathrm{~g})$ was packed in muslin cloth and subjected to Soxhlet extraction for continuous extraction with methanol for $72 \mathrm{~h}$. Methanolic extract of A. pavonina was filtered through Whattmann filter paper and filtrate was concentrated under reduced pressure and at temperature below $40^{\circ} \mathrm{C}$. Dried extract was stored in freezer.

\section{Preliminary phytochemical screening}

Preliminary phytochemical investigation was performed for the presence or absence of palnt constituents like alkaloids, glycosides, carbohydrates, phenolic compounds, tannins, flavonoids, terpenoids, saponins, sterols, proteins and resins in MEAP.

\section{Estimation of ash value}

Ash value was determined by the method described by Choudhry, (1996). The ash remaining following ignition at $450^{\circ} \mathrm{C}$ of crude drug was determined by three different methods, which measure total ash, acidinsoluble ash and water-soluble ash ${ }^{17}$.

\section{Total ash}

Indian Pharmacopoeia 1996 and WHO prescribes methods for determination of ash values. About 2-3 gm of air dried crude drug was placed in the tarred silica crucible and was incinerated at a temperature not exceeding $450^{\circ} \mathrm{C}$ until free from carbon, cooled and weighed to get the total ash content.

\section{Acid insoluble ash}

Acid insoluble ash is the residue obtained after boiling the total ash with dilute hydrochloric acid and igniting the remaining insoluble matter. This measures the amount of silica present, especially as sand and siliceous earth. Ash was boiled with $25 \mathrm{ml}$ of hydrochloric acid for 5 minutes. The insoluble matter was collected on ash less filter paper, washed with hot water and ignited at a temperature not exceeding $450^{\circ} \mathrm{C}$ to a constant weight.

\section{Water soluble ash}

Water soluble ash is the difference in weight between the total ash and the residue after treatment of total ash with water. It is a good indicator of either previous extraction of water-soluble salts in the drug or in corrected preparation. Ash was dissolved in distilled water and the insoluble part collected on an ashless filter paper and was ignited at $450^{\circ} \mathrm{C}$ to a constant weight. By subtracting the weight of insoluble part from that of ash, the weight of the soluble part of ash was obtained.

\section{Estimation of loss on drying}

This parameter determines the amount of moisture as well as volatile components present in a particular sample. The powdered drug sample (10 gm) was placed on a tarred evaporating dish and dried at $105^{\circ} \mathrm{C}$ for $6 \mathrm{hrs}$ and weighed. The drying was continued until two successive reading matched each other or the difference between two successive weighing was not more than $0.25 \%$ of constant weight ${ }^{18}$.

\section{Estimation of extractive value}

According to Indian Pharmacopoeia 1996, British Pharmacopoeia 1980 and WHO guideline the determination of water soluble and alcohol soluble extractives is used as a means of evaluating crude drugs which are not readily estimated by other means. The extraction of any crude drug with particular solvent yields a solution containing different phytoconstituents that is such extractive value provides an indication of the extent of polar, medium polar and non polar components present in the plant material ${ }^{17,19}$.

\section{Estimation of total phenolic content}

Total phenolic content was determined according to colorimetric principle ${ }^{20}$. $10 \mathrm{mg} / \mathrm{ml}$ solution of the MEAP was prepared in methanol. Different dilutions of gallic acid $(5 \mu \mathrm{g} / \mathrm{ml}$ to $75 \mu \mathrm{g} / \mathrm{ml})$ were prepared in methanol. Methanol was used as blank. $10 \%$ FolinCiocalteu Reagent (FCR) in distilled water, $1 \mathrm{M} \mathrm{Na}_{2} \mathrm{CO}_{3}$ solution in distilled water and $1 \mathrm{mg} / \mathrm{ml}$ solution of standard gallic acid in methanol were prepared. $0.5 \mathrm{ml}$ of each standard dilution or drug sample solution or blank was taken and, added to $5 \mathrm{ml} \mathrm{FCR} \mathrm{reagent} \mathrm{and} 4$ $\mathrm{ml} \mathrm{Na}{ }_{2} \mathrm{CO}_{3}$ solution. Then, absorbance was taken at 725 $\mathrm{nm}$ after 40 minutes. Standard calibration curve was plotted. Total phenolic content in the extract was calculated by using this curve. It was found to be $55.43 \pm 1.07 \mu \mathrm{g} / \mathrm{mL}$.

\section{Estimation of total flavonoid content}

Total flavonoid content was estimated by colorimetric principle of aluminium chloride method ${ }^{21} .0 .5 \mathrm{ml}$ of the $1 \mathrm{mg} / \mathrm{ml}$ stock solution of MEAP prepared in methanol was taken in $1.5 \mathrm{ml}$ of methanol in a test tube. $0.1 \mathrm{ml}$ of $1 \mathrm{M}$ potassium acetate solution was added to reaction mixture and volume was made upto $5 \mathrm{ml}$ with distilled 
water. Then, it was incubated at room temperature for 30 min with intermittent shaking and absorbance was measured at $514 \mathrm{~nm}$. The experiment was also performed for different dilutions of standard rutin (10$125 \mu \mathrm{g} / \mathrm{ml}$ ) in methanol and calibration curve was plotted. Total flavonoid content was expressed as rutin equivalent to $\mu \mathrm{g} / \mathrm{mL}$ extracts.

\section{In Vitro Scavenging Assays}

\section{Assay for DPPH free radical scavenging capacity}

The assay was performed according to the method of Lim ${ }^{22}$. The radical scavenging activity of MEAP against 1,1-Diphenyl-2-picrylhydrazyl (DPPH) was determined by UV spectrophotometer at $517 \mathrm{~nm}$. An aliquot of $(0.05,0.1,0.51 .0,1.25$ and $1.50 \mathrm{mg} / \mathrm{ml})$ of MEAP was mixed in test tubes containing $3 \mathrm{ml}$ of methanol and $0.5 \mathrm{ml}$ of $1 \mathrm{mM}$ DPPH. The reaction mixture was incubated at $37^{\circ} \mathrm{C}$ for $30 \mathrm{~min}$. The radical scavenging activity was calculated using the following equation-

\section{$\%$ Scavenging $=[1-($ Absorbance of Sample/Absorbance of Control)] $\times 100$.}

Ascorbic acid was used as standard and methanol was used as blank (control). Experiment was performed three times.

\section{Assay for nitric oxide anion scavenging activity}

The procedure was based on the principle that sodium nitroprusside solution at physiological $\mathrm{pH}$ spontaneously generates nitric oxide which interacts with oxygen to produce nitric ion that was estimated by using Greiss reagent (1\% sulphanilamide, $2 \%$ phsphoric acid and $0.1 \%$ naphthylenediamine dihydrochloride) ${ }^{23}$. Scavenger of nitric oxide competes with oxygen leading to reduce production of nitric ion. $1 \mathrm{ml}$ aliquot of different concentrations of MEAP $(0.05-1.5 \mathrm{mg} / \mathrm{ml})$ were dissolved in phosphate buffer solution. $1 \mathrm{ml}$ of 10
$\mathrm{mM}$ sodium nitropruside solution was added to it and incubated at room temperature for $150 \mathrm{~min}$. The reaction without the extract but equivalent amount of methanol served as control. After incubation period, 0.5 $\mathrm{ml}$ of Greiss reagent was added. The absorbance was determined by UV spectrophotometer at $546 \mathrm{~nm}$. Ascorbic acid was used as standard. Experiment was performed three times.

The radical scavenging activity was calculated using the following equation-
$\%$ Scavenging $=[1-($ Absorbance of Sample/Absorbance of Control) $] \times 100$.

\section{Assay for reducing power}

The total reducing power of the extract was measured according to Oyaizu method (1986). Extract MEAP dissolved in $1 \mathrm{ml}$ of distilled water $(10,25,50$ and 100 $\mathrm{mg} / \mathrm{ml})$ was mixed with $2.5 \mathrm{ml}$ of phosphate buffer $(0.2$ $\mathrm{mM}, \mathrm{pH} 6.6$ ) and $1 \%$ of $2.5 \mathrm{ml}$ potassium ferricyanide. The mixture was then incubated at $55^{\circ} \mathrm{C}$ for $25 \mathrm{~min}$. Subsequently, $2.5 \mathrm{ml}$ of $10 \%$ trichloroacetic acid was added to the mixture, which was then centrifuged for 10 $\min$ at $3000 \mathrm{rpm}$. The upper layer of the solution (1.5 $\mathrm{ml}$ ) was mixed with $1.5 \mathrm{ml}$ of distilled water and $0.3 \mathrm{ml}$ of $0.1 \%$ ferric chloride solution. The absorbance was measured at $680 \mathrm{~nm}$ using UV spectrophotometer. Elevated absorbance of the reaction mixture indicated better reducing power ${ }^{24}$. Experiment was performed three times.

\section{RESULTS}

\section{Preliminary phytochemical screening}

The results of preliminary phytochemical investigation showed the presence of alkaloids, glycosides, carbohydrates, phenolic compounds, tannins, flavonoids, terpenoids, saponins, sterols, proteins and resins in MEAP (Table 1).

Table 1: Phytochemical screening of methanolic extract of A. pavonina leaves.

\begin{tabular}{|l|l|l|}
\hline Sl. No. & Constituents & Observation \\
\hline 1 & Alkaloids & + \\
\hline 2 & Carbohydrates & + \\
\hline 3 & Glycosides & + \\
\hline 4 & Phenolic compounds and tannins & + \\
\hline 5 & Flavonoids & + \\
\hline 6 & Terpenoids & + \\
\hline 7 & Saponins & + \\
\hline 8 & Sterols & + \\
\hline 9 & Proteins & + \\
\hline 10 & Resins & + \\
\hline 11 & Lipids/ Fats & - \\
\hline
\end{tabular}

\section{Estimation of ash value}

The results of ash value of A.pavonina are mentioned in Table 2. Total ash, acid insoluble and water soluble ash values of $A$. pavonina were found to be $8.86,2.24$ and $7.18 \% \mathrm{w} / \mathrm{w}$ respectively with respect to air-dried crude drug. 
Table 2: Ash values of A. pavonina leaves.

\begin{tabular}{|l|l|l|l|}
\hline Sl. No. & Total ash $\mathbf{( \% )}$ & Acid insoluble ash $\mathbf{( \% )}$ & Water soluble ash $(\boldsymbol{\%})$ \\
\hline 1 & 8.91 & 2.51 & 7.12 \\
\hline 2 & 8.71 & 2.23 & 7.45 \\
\hline 3 & 8.99 & 1.99 & 6.98 \\
\hline Mean & 8.86 & 2.24 & 7.18 \\
\hline
\end{tabular}

\section{Estimation of loss on drying}

The loss on drying of $A$. pavonina leaves had been determined. It was found to be $1.53 \% \mathrm{w} / \mathrm{w}$.

\section{Estimation of extractive value}

The yield of methanolic extract of Adenanthera pavonina leaves (MEAP) was found to be $11.2 \% \mathrm{w} / \mathrm{w}$.
Estimation of total phenolic and flavonoid contents

Total phenolic and flavonoid contents in the methanolic extract of $A$. pavonina leaves (MEAP) were found to be $55.43 \pm 1.07 \mu \mathrm{g} / \mathrm{ml}$ equivalent to gallic acid and $52.87 \pm 1.8 \mu \mathrm{g} / \mathrm{ml}$ equivalent to rutin respectively (Figure 1 and Figure 2).

\section{Gallic acid plot}

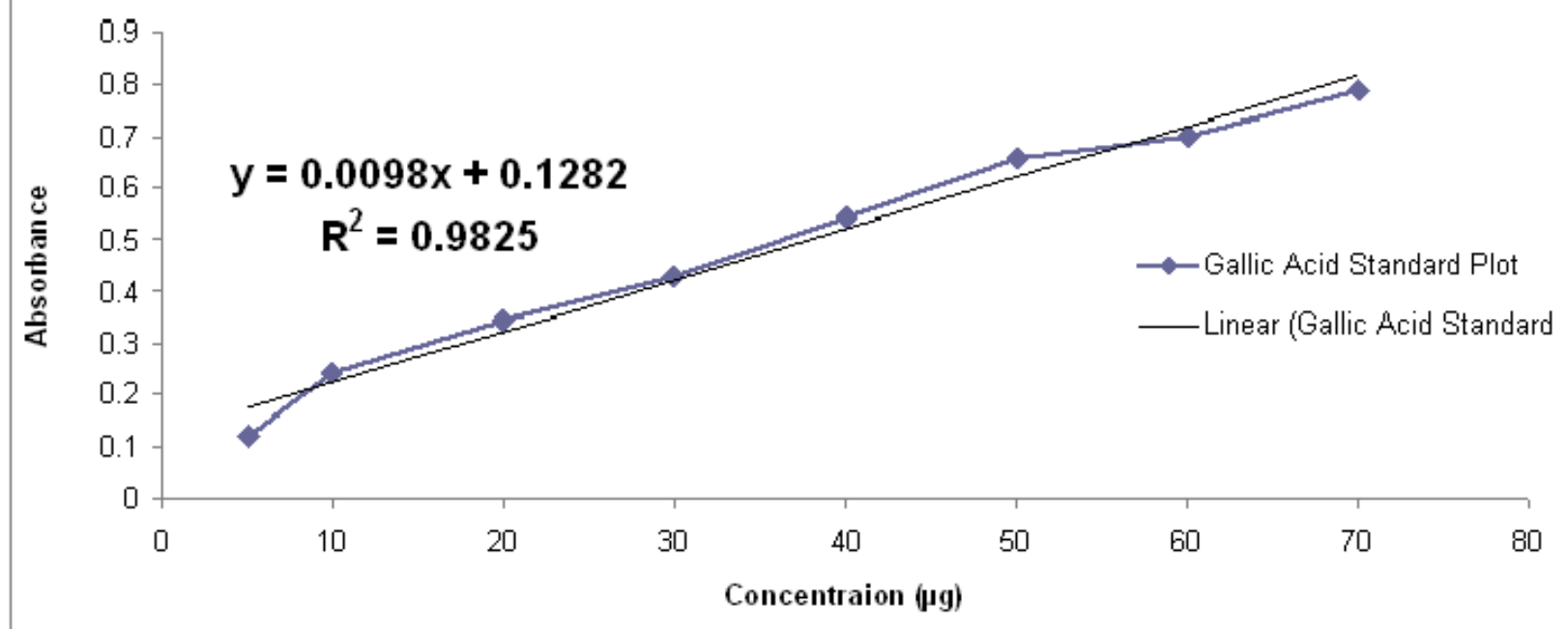

Figure 1: Gallic acid calibration curve for estimation of total phenolic content.

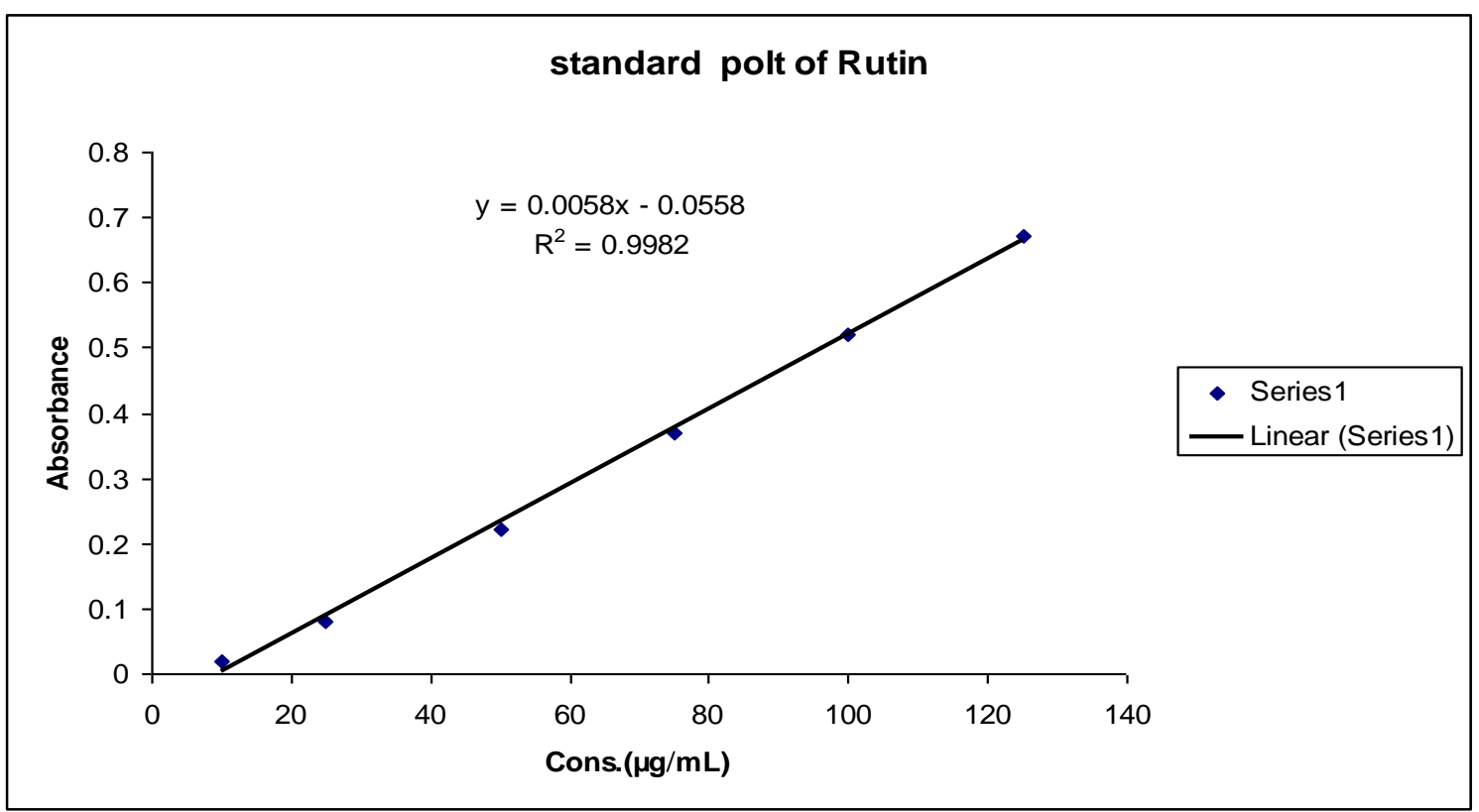

Figure 2: Rutin calibration curve for estimation of total flavonoid content. 


\section{In Vitro Scavenging Assays}

\section{Assay for DPPH free radical scavenging capacity}

The scavenging effect of MEAP was found to be concentration dependent. MEAP reacted with the stable free radical DPPH and discolored its solution. The percentage inhibition by MEAP at different concentrations of $0.05,0.1,0.5,1.0,1.25$ and 1.50 $\mathrm{mg} / \mathrm{ml}$ were found to be $34.14,39.29,51.27,75.32$,
87.18 and $93.09 \%$ respectively whereas, in comparably doses, that of the standard ascorbic acid were found to be $38.92,44.35,53.87,78.52,89.21$ and $99.01 \%$ respectively. The standard ascorbic acid presented a high scavenging effect of $99.01 \%$ at the concentration of $1.50 \mathrm{mg} / \mathrm{ml}$. The $\mathrm{IC}_{50}$ value of MEAP was found to be $425 \mu \mathrm{g} / \mathrm{ml}$, which is comparable to the $\mathrm{IC}_{50}$ of standard ascorbic acid $320 \mu \mathrm{g} / \mathrm{ml}$ (Figure 3).

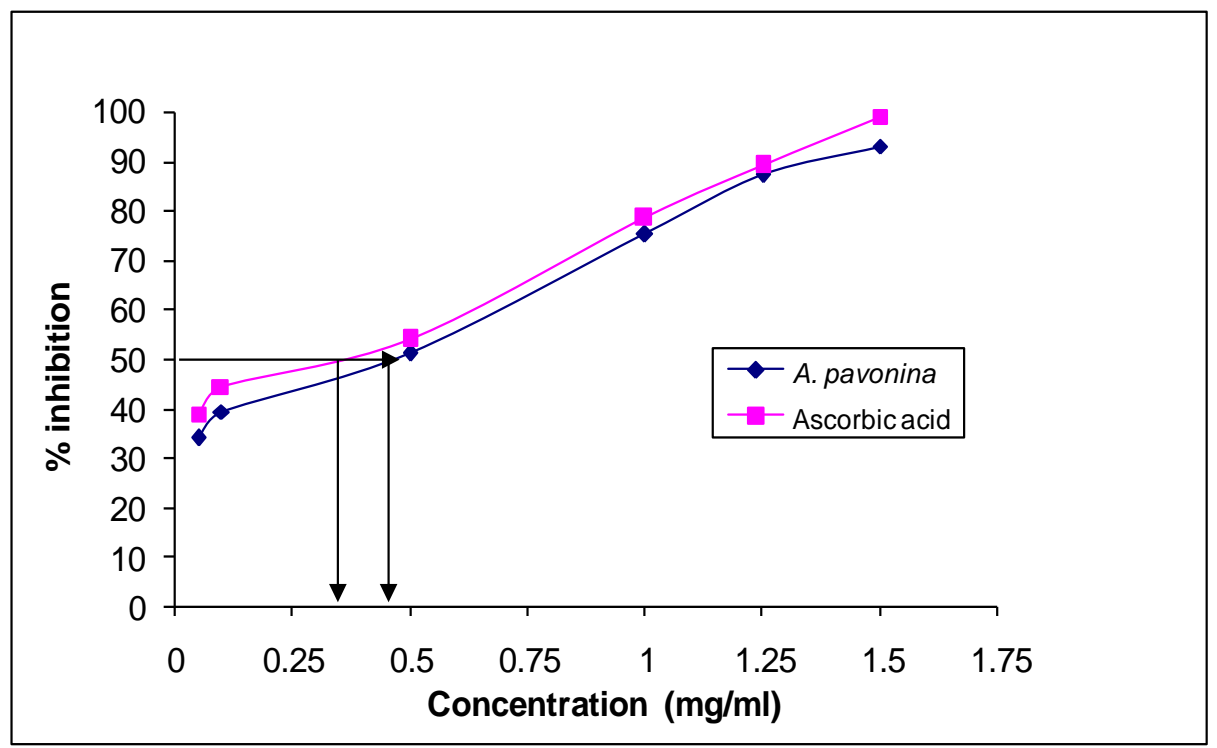

Figure 3: DPPH free radical scavenging activity of methanolic extract of A. pavonina leaves.

\section{Assay for nitric oxide anion scavenging activity}

MEAP produced significant free radical scavenging action against nitric oxide (NO) induced release of free radicals. The percentage inhibitions at different concentrations of standard ascorbic acid 0.05, 0.10, 0.5, $1.0,1.25$ and $1.5 \mathrm{mg} / \mathrm{ml}$ were found to be $37.99,44.02$, $57.40,80.01,89.60$ and $96.05 \%$ and that of the MEAP at the same concentrations were found to be 33.98, $40.26,52.32,69.87,80.18$ and 91.64 respectively. The standard ascorbic acid presented a high scavenging effect of $95.32 \%$ at the concentration of $1.5 \mathrm{mg} / \mathrm{ml}$. The $\mathrm{IC}_{50}$ of MEAP was found to be $352 \mu \mathrm{g} / \mathrm{ml}$, which was comparable to the $\mathrm{IC}_{50}$ of standard ascorbic acid 280 $\mu \mathrm{g} / \mathrm{ml}$ (Figure 4).

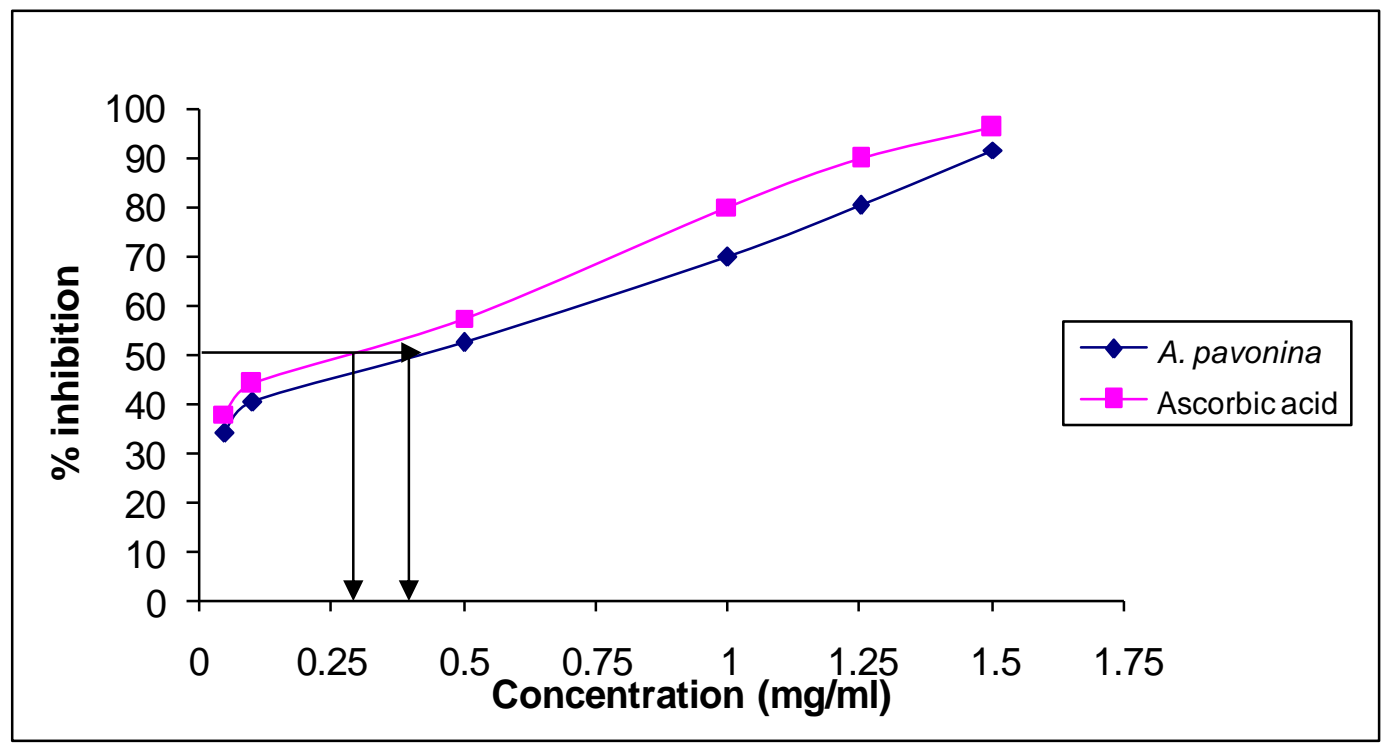

Figure 4: Nitric oxide anion scavenging activity of methanolic extract of $A$. pavonina leaves.

\section{Assay for reducing power}

The reducing capacity of the extract MEAP at different concentration ranging from $10-100 \mathrm{mg} / \mathrm{ml}$ revealed significant reducing activity in terms of ascorbic acid equivalent (Table 3). Its reducing power was found to be dose dependent. Results are expressed as Mean \pm SD average of three experimental values. 
Table 3: Reducing ability of methanolic extract of $A$. pavonina leaves.

\begin{tabular}{|c|c|c|c|}
\hline $\begin{array}{l}\text { Sl. } \\
\text { No. }\end{array}$ & $\begin{array}{c}\text { Concentration(m } \\
\mathrm{g} / \mathrm{ml})\end{array}$ & $\begin{array}{c}\text { Absorbance (ascorbic acid) } \\
(\text { (Mean } \pm \text { SD) }\end{array}$ & $\begin{array}{c}\text { Absorbance (A. pavonina) } \\
(\text { Mean } \pm \text { SD) }\end{array}$ \\
\hline 1 & 10 & $0.407 \pm 0.026$ & $0.296 \pm 0.071$ \\
\hline 2 & 25 & $0.495 \pm 0.082$ & $0.398 \pm 0.046$ \\
\hline 3 & 50 & $0.598 \pm 0.095$ & $0.403 \pm 0.064$ \\
\hline 4 & 100 & $0.682 \pm 0.136$ & $0.491 \pm 0.079$ \\
\hline
\end{tabular}

\section{DISCUSSION AND CONCLUSION}

Various evidences indicate that increased consumption of antioxidants from fruits and vegetables minimizes the risk of degenerative diseases associated with ageing and may contribute to improvement in quality of life by delaying the onset of various diseases ${ }^{25}$. The present results demonstrated that MEAP possess free radical scavenging and antioxidant capacity as tested in in vitro. It demonstrated the effect polyvalent phytophore and its scavenging capacity in in vitro assays ${ }^{26}$. In addition to phenolic compounds, natural flavonoids and terpenes from herbs or plant extracts are considered as most important antioxidant components and direct correlation has been established between total phenolic content and flavonoidal content of the extracts and antioxidant capacity in vitro ${ }^{27}$. Free radical scavenging capacity of extract MEAP was investigated by DPPH, nitric oxide and reducing power assays. The results from DPPH assay revealed that MEAP has shown efficient quenching of DPPH and nitric oxide and thus contains free radical quenching compounds which act as primary radical scavenger that react with DPPH by providing a hydrogen atom or electron donating ability 28. MEAP showed high $\mathrm{IC}_{50}$ values which are comparable to that of standard ascorbic acid. The reducing potential of a compound may be referred as an important marker of its possible antioxidant activity ${ }^{29}$.

\section{REFERENCES}

1. Maxwell SR, Lip GY. Free radicals and antioxidants in cardiovascular disease. Br J Clin Pharmacol 1997;44:30717.

2. Pryor WA. Free radical reactions and their importance in bio-chemical systems. Fed Proc 1973;32:1862-9.

3. Niki E. Assessment of antioxidant capacity in vitro and in vivo. Free Radic Biol Med 2010;49:503-5.

4. Halliwell B. Antioxidants: The basics- what they are and how to evaluate them. Adv Pharmacol 1997;38:3-20.

5. Huang D, Ou B, Prior RL. The chemistry behind Antioxidant capacity Assays. J Agric Food Chem 2005;53(6): 1841-56.

6. Chopra RN, Nayar SL, Chopra IC. Glossary of Indian Medicinal Plants. New Delhi:CSIR; 1956:6.

7. Burkill IH. A Dictionary of the Economic Products of the Malay Peninsula. Edited by: Ministry of Agriculture (Malaysia). London: Crown Agents for the Colonies; 1966:839.

8. Mujahid M, Siddiqui HH, Hussain A, Hussain MS Hepatoprotective effects of Adenanthera pavonina (Linn.) against anti-tubercular drugs-induced hepatotoxicity in rats. Pharmacog J 2013;5(6):286-90.

9. Khare CP. Indian Medicinal PlantsdAn Illustrated Dictionary. Berlin: Springer-Verlag; 2007:601.

10. Howes FN. A Dictionary of Useful Everyday Plants and Their Common Names. Cambridge University Press; 1974:15.
However, the antioxidant activity of presumed antioxidants has been allowed to occur by various mechanisms. Anticipation of chain initiation, binding of transition metal ion catalysts and decomposition of peroxides are some mechanisms among them. Prevention is continued by hydrogen abstraction and radical scavenging ${ }^{30}$. Reducing capability of MEAP was compared with standard ascorbic acid ${ }^{31-33}$.

The results of the study indicated that anti-oxidant activities of phenolic and flavonoidal compounds are responsible for the scavenging and anti-oxidant activities of methanolic extract of $A$. pavonina leaves (MEAP). MEAP is a potent scavenger of ROS and can counteract oxidative damages by ROS. Thus, MEAP can be employed as an anti-oxidant drug to counteract and treat oxidative damages by ROS.

\section{CONFLICT OF INTERESTS}

Authors declare that they have no conflict of interest.

\section{Source(s) of support: Nil}

\section{ACKNOWLEDGEMENT}

One of the authors is thankful to Faculty of Pharmacy, Integral University Lucknow (IUL) for providing the necessary facilities to carry out this research.

11. Yadav N, Misra G, Nigram SK. Triterpenoids from Adenanthera pavonina bark. Planta Med 1976;29:176-8.

12. Muhammad SA, Farman A, Iqbal A, Muhammad KP. Pavonin: a new five membered lactone from Adenanthera pavonina Linn. (Mimiaceae). Nat Prod Res 2005;9:37-40.

13. Olajide OA, Echianu CA, Adedapo AD, Makinde JM. Antiinflammatory studies on Adenanthera pavonina seed extract. Inflammopharmacology 2004;12:196-202.

14. Aduragbenro D, Adedapo A, Yeside O. Blood pressure lowering effect of Adenanthera pavonina seed extract on normotensive rats. Rec Nat Prod 2009;32:82-9.

15. Rodrigo SK, Jayasinghe ULB, Bandara BMR. Antifungal, antioxidant and cytotoxic activity of Acronychia pedunculata and Adenanthera pavonina. In: Proceedings of the Peradeniya University Research Sessions, Sri Lanka. 2007;vol. 12:94-5.

16. Rastogi, Mehrotraa. Compendium Indian Medicinal Plants. vol. 2. New Delhi:PID; 1991:23.

17. Choudhry RD. A Practical approach to industrial Pharmacognosy. Herbal drug Industries 1st edition, Eastern Publishers:New Delhi. 1996;353-6.

18. Gupta AK. Quality standards of Indian medicinal plants, vol. 1, Indian Council of Medical Research. 2003;57-81.

19. Anonyms. The Ayurvedic Pharmacopoeia of India, part-I, Vol. II. 1st edition, New Delhi:Government of India, Ministry of Health and Family Welfare, Department of Indian system of Medicine \& Homeopathy. 1999;189-96. 
20. Rahman MA, Hussain A. Anticancer activity and apoptosis inducing effect of methanolic extract of Cordia dichotoma against human cancer cell line. Bangladesh J Pharmacol 2015;10:27-34.

21. Chang C, Yang M, Wen H, Chern J. Estimation of total flavonoid content in propolis by two complementary colorimetric methods. J Food Drug Anal 2002;10:178-82.

22. Lim KT, Hu C, Kitts DD. Antioxidant activity of a Rhus verniciflua stokes ethanol extract. Food Chem Toxicol 2001;39: 229-37.

23. Sreejayan N, Rao MNA. Nitric oxide scavenging activity of curcumonoids. J Phar Pharmacol 1997;49(1):105-7.

24. Oyaizu M. Studies on product of browning reaction prepared from glucoseamine. Japanese J Nutr 1986;44:307-15.

25. Rattanachitthawat $S$, Suwannalert $P$, Riengrojpitak $S$, ChaiyasutC, Pantuwatana S. Phenolic content and antioxidant activities in red unpolished Thai rice prevents oxidative stress in rats. J Med Plants Res 2010;4(9):796-801.

26. Kratchanova M, Denev P, Ciz M, Lojek A, Mihailov A. Evaluationof antioxidant activity of medicinal plants containing polyphenol compounds,comparison of two extraction system. Acta Biochemica Polanica 2010;57(2):229-34.
27. Bozin B, Mimica-Dukic N, Samojlik I, Goran A, Igic R. Phenolics as antioxidants in garlic (Allium sativum L., Alliaceae). Food Chem 2008;111:925-9.

28. Hussain MS, Nazeer-Ahmed KFH, Ansari MZH. Studies on diuretic activity of Hygrophila auriculata (Schum) Heine in rats. Int J Health Res 2009;2(1):59-64.

29. Ryan L, Prescott SL. Stability of the antioxidant capacity of twenty-five commercially available fruit juices subjected to an in vitro digestion. Int J Food Sci Tech 2010;45:1191-7.

30. Akillioglu HG, Karakaya S. Changes in total phenols, total flavonoids, and antioxidant activities of common beans and pinto beans after soaking, cooking, and in vitro digestion process. Food Sci Biotechnol 2010;19:633-9.

31. Meydani M, Lipman RD, Han SN. The effect of long-term dietary supplementation with antioxidants. Annals New York Acad Sci 1998;854:352-60.

32. Pellegrini N, Simonetti P, Gardana C, Brenna O, Brighenti F, Pietta P. Polyphenol content and total antioxidant activity of Vini novelli (Young red wines). J Agric Food Chem 2000;48(3):732-5.

33. Umiel NB, Friedman H. Rose Petal Tea as an Antioxidantrich Beverage: Cultivar Effects. J Food Sci 2006;71:S42-7. 